\section{Consultant Crisis}

Those barometers of professional opinion the correspondence columns have been registering a rising pressure of discontent among consultants for some time. One cause of this, inadequate pay, has been about ever since the N.H.S. started, but this is not the only cause. The population's increasing demands on the N.H.S., the Service's chronic inability to project much of its working environment into the 20th century, and, more recently, the serious shortages of nurses and ancillary workers have all contributed to the consultants' difficulties. In addition they have watched-and in general welcomed-the junior staffs battling for improved working conditions, but inevitably this has increased their own load. So, despite a continuing expansion in the number of consultants-551 were appointed in the U.K. in 1971-2, bringing the total on 30 September 1972 to 10,919 -today too many consultants find themselves overworked, and their professional satisfaction dwindling.

Consultants from district hospitals are very well represented in the Central Committee for Hospital Medical Services. Indeed, one of their number (Dr. C. E. Astley) is the chairman, and another (Mr. A. H. Grabham) leads the negotiating team, so that their particular problems are well known to the B.M.A. In the Supplement this week (pp. 76 and 79) Mr. Grabham and Mr. R. Myles Gibson, the two deputy chairmen of the committee, discuss the present situation and are commendably frank in describing the difficulties of the C.C.H.M.S. in resolving the crisis. As with general practice in the early ' 60 s and with the juniors later in the decade the crisis is one of confidence in the Government's willingness or ability to act. With history repeating itself this loss of confidence has rubbed off on the body responsible for representing the profession-namely, the B.M.A.

Has the C.C.H.M.S. been dilatory in telling the Government how grave is the staffing crisis and how far hospital doctors' morale has fallen? In 1966 (the year of the G.P.s' successful negotiations on their charter) the B.M.A. presented the Government with a comprehensive charter for hospital doctors, ${ }^{1}$ setting out their problems and suggesting remedies. Since then there have been many negotiations, further reports ${ }^{2}$-and some Government action. But most senior hospital doctors think that the action has been woefully inadequate. Reasonably enough they ask why if the G.P.s took about two years to achieve their major reforms the consultants still have not reached their objective.

Some of the reasons for the delay are given by $\mathrm{Mr}$. Grabham in his interview. In contrast to general practice the hospital service is complex and very expensive. The variety of hospitals, the large number of specialties, the complicated staffing structure (with the need to balance training programmes against service needs), and the hospitals' dependence on many technical and other supporting staff mean that such problems cannot be solved quickly. An ideal answer for the complaints of one group may have unacceptable consequences for another, and the necessary resulting compromise probably pleases neither side. Indeed, to some extent the C.C.H.M.S. is suffering from the very success achieved by the juniors, who until this year formed a large constituent part of it. The Government was clearly prepared to give way on the juniors' front because the unrest and shortages there were acute. The Government must have realized, however, that its concessions would inevitably affect senior doctors, and it is they who now urgently need relief

In dealing with the Government general practitioners have two advantages over hospital staff. Firstly, their political experience in state medicine stretches back to 1912 and they have a strong local and national tradition of medicopolitical activity. Secondly, their status as independent contractors with the N.H.S. gives them an ultimate bargaining weapon. In their local committee activities consultants (as Mr. Gibson observes in his interview) are much more clinically-orientated and they tend to avoid involvement in medicopolitics. This is understandable but, sadly, unrealistic in a state service. If consultants wish to compel the Government to deal with their problems they must ensure that their representative machinery is properly used both locally and nationally so that their negotiators have their undoubted widespread and determined support in any confrontation.

Many senior medical staff have been reluctant to accept the concept behind the new proposals for the new contract put forward by the C.C.H.M.S., ${ }^{4}$ seeing it as antipathetic to their professional ethic. But the C.C.H.M.S. considered that its proposals were the only way of forcing the Government to recognize the greatly increased work load and responsibilities facing consultants. The restraints of the Government's counter-inflation policy have temporarily halted progress on negotiating this contract, but consultants should put this enforced rest to good use by marshalling their considerable medicopolitical potential. In this way when the time comes for negotiation the Government will be left in no doubt at all about where hospital doctors stand. In a time of national economic crisis a profession may well be reluctant to use its power but there is no reason why doctors should not make it clear that they expect the Government to treat them as fairly as the rest of the community. Some aspects of phase 3 hospital doctors could possibly turn to their advantage, for instance, extra payment for new work, but to do this the negotiators will require the profession's wholehearted support.

At a time when the established negotiating body seems to be making slow progress it is tempting for some doctors to turn in their frustration to bodies which seem specially to represent their own point of view or sectional interest. Pressure groups have a useful, indeed, essential part to play in the political processes. But negotiating with the Government takes money, time, and experience as well as making heavy demands on the elected leaders of the profession. Pressure groups usually specialize in well-publicized and carefully timed criticism, but may well be out of their financial and administrative depth if they n!ove outside this role. Unity is an overused word but in the crisis which consultants now face only concerted and active support of the C.C.H.M.S. locally and nationally can offer any real prospect of success.

1 British Medical Fournal Supplement, 1967, 2, 93.

2 British Medical Fournal Supplement, 1969, 4, 53.

3 British Medical fournal Supplement, 1973, 1, 73.

4 British Medical fournal Supplement, 1972, 3, 39. 